\title{
Determination of Heavy Metals in Raw Milk Produced in Tangshan City, China
}

\author{
Aijun $\mathrm{Li}^{1}$, Ruihuan $\mathrm{Du}^{1, \mathrm{a}}$, Baiqin Zheng ${ }^{1}$, Junli Meng ${ }^{1}$, Jianmin Zhang ${ }^{1}$, Aili Xiang ${ }^{1}$, Xin Zhang $^{1}$, Biao $\mathrm{Qi}^{2}, \mathrm{Ying} \mathrm{Wu}^{3}, \mathrm{Xin}$ \\ Zhou $^{1}$, Yi Zhang ${ }^{1}$, Lixue Dong ${ }^{1}$, Xueliang Pang ${ }^{1}$ \\ ${ }^{1}$ Tangshan Livestock and Aquatic Products Quality Monitoring Center, Tangshan, Hebei 063000 ,China \\ ${ }^{2}$ The Central Agricultural Broadcasting and Television School of Tangshan Branch, Tangshan 063000, China \\ ${ }^{3}$ Tangshan Science and Technology Information Institute, Tangshan 063000, China
}

\begin{abstract}
The objective of this study was to investigate the content of heavy metals (Arsenic, Lead, Chromium and Mercury) in raw milk of Tangshan. Samples were obtained directly from dairy farms in Tangshan City. A total of 55 raw milk samples were collected in 2012, a total of 150 raw milk samples and 150 in 2013 and 2014 respectively. All the samples were analyzed by ICP-MS (Inductively Coupled Plasma Mass Spectrometry) method-based on China National Standard. In general, heavy metals (Arsenic, Lead, Chromium and Mercury) of raw milk in Tangshan were relatively safe for people's health because none of those heavy metals (Arsenic, Lead, Chromium and Mercury) contents exceeded the Maximum Limit set by China.
\end{abstract}

\section{Introduction}

Raw milk is considered as an extremely nutritious food and rich in vitamin $\mathrm{D}$, calcium, and protein, substances essential for construction of muscle, bone and other tissues $^{[1,2]}$. However, milk may contain lots of refractory substances, such as heavy metals(Arsenic, Lead, Chromium and Mercury), which can be potentially harmful to human health ${ }^{[2,3]}$.

Heavy metals tend to accumulate in the body, eventually to the extent of being toxic to humans ${ }^{[4,5]}$. Arsenic causes skin disorders, which is subject to abnormal keratinization ${ }^{[6,7]}$. Arsenic may also lead to skin pigmentation, nervous indigestion, progressively destroying metabolic system of body cells ${ }^{[8,9]}$. The harmfulness of lead on children's growth and intelligence behavior is especially serious. As is well known, Lead may damage the kidney, liver and reproductive system, basic cellular processes and brain function. Also lead may damage children's intelligence. Particularly the children's brain may stop developing ${ }^{[10,11]}$.

Chromium is easily absorbed by the human body, which may promote cancer. Mercury causes nervous system disorder and poses a grave threat to human health ${ }^{[12,13]}$. Mercury is a potent neurotoxin that can harm a developing fetus. Studies performed in Raw Milk in Tangshan City, indicate that we should pay special attention to foodstuff and regularly monitor pollutants in food ${ }^{[5,14]}$.

\section{Materials and methods}

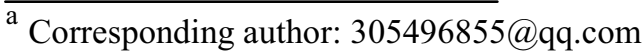

\subsection{Sampling procedures}

Samples were obtained directly from dairy farms in Fengnan, Guye, Liaoting, Fengrun districts of Tangshan City $^{[9]}$. There were 55, 150 and 150 raw milk samples collected in 2012, 2013, and 2014, respectively.

Sampling collectors include sterile sample bottles and beakers, which had been cleaned with $75 \%$ alcohol and last remaining alcohol was burned ${ }^{[9,14]}$. All the containers kept dry and sterile in the whole process ${ }^{[15]}$. Every sample was collected into three bottles. Two of them were used in the paralleled detection, and the third one would be preserved for three months just in case. After being well mixed and completely incorporated, $200 \mathrm{~mL}$ raw milk in each bottle was recollected from the top, middle, and bottom of its container, respectively ${ }^{[15]}$. Then $300 \mathrm{~mL}$ raw milk was removed and put into sterile sampling bottles, which was stored at $4{ }^{\circ} \mathrm{C}$ during our three hours' sampling trip ${ }^{[9,16] .}$ The studies were performed as soon as we arrived at the laboratory.

\subsection{Chemicals}

The reagents and chemicals used were Merck (Darmstadt, Germany), which is analytical grade ${ }^{[9,17]}$. Concentrated nitric acid $(65 \%)$ was guarantee reagent producted by Merck (Darmstadt, Germany). De-ionized water was used during the whole experimental process. 


\subsection{Sample analysis}

In this study, four heavy metals ( Arsenic, Lead, Chromium and Mercury) in the collected raw milk were studied by ICP-MS in order to evaluate its quality ${ }^{[17]}$.

Tables respectively show the amount of Lead, Arsenic, Chromium and Mercury in milk sample at different concentrations.

Table 1. Level of Lead in raw milk in 2012, 2013, 2014.

\begin{tabular}{|c|c|c|c|c|c|}
\hline Year & $\begin{array}{c}\text { Sample } \\
\text { size }\end{array}$ & $\begin{array}{c}\text { Undetected } \\
\text { no.(\%) }\end{array}$ & $\begin{array}{c}\text { Maxim } \\
\mathrm{um} \\
(\mathrm{mg} / \mathrm{kg})\end{array}$ & $\begin{array}{c}\text { Mean } \\
(\mathrm{mg} / \mathrm{kg})\end{array}$ & $\begin{array}{c}\text { Maximum } \\
(\mathrm{mg} / \mathrm{kg}) \\
\text { Set by } \\
\text { China }\end{array}$ \\
\hline 2012 & 55 & $1(1.82)$ & 0.048 & 0.023 & 0.05 \\
\hline 2013 & 60 & $2(3.00)$ & 0.040 & 0.019 & \\
\hline 2014 & 133 & $46(34.5)$ & 0.037 & 0.012 & \\
\hline
\end{tabular}

Table 2. Level of Arsenic in raw milk in 2014.

\begin{tabular}{|l|l|l|l|l|l|}
\hline Year & $\begin{array}{c}\text { Sample } \\
\text { size }\end{array}$ & $\begin{array}{c}\text { Undetected } \\
\text { no. }(\%)\end{array}$ & $\begin{array}{c}\text { Maximum } \\
(\mathrm{mg} / \mathrm{kg})\end{array}$ & $\begin{array}{c}\text { Mean } \\
(\mathrm{mg} / \mathrm{kg})\end{array}$ & $\begin{array}{c}\text { Maximum } \\
(\mathrm{mg} / \mathrm{kg}) \\
\text { Set by } \\
\text { China }\end{array}$ \\
\hline 2014 & 133 & $91(68.4)$ & 0.031 & 0.017 & 0.05 \\
\hline
\end{tabular}

Table 3. Level of Chromium in raw milk in 2013, 2014.

\begin{tabular}{|c|c|c|c|c|c|}
\hline Year & $\begin{array}{c}\text { Sample } \\
\text { size }\end{array}$ & $\begin{array}{c}\text { Undetected } \\
\text { no.(\%) }\end{array}$ & $\begin{array}{c}\text { Maxim } \\
\mathrm{um} \\
(\mathrm{mg} / \mathrm{kg})\end{array}$ & $\begin{array}{c}\text { Mean } \\
(\mathrm{mg} / \mathrm{kg})\end{array}$ & $\begin{array}{c}\text { Maximum } \\
(\mathrm{mg} / \mathrm{kg}) \\
\text { Set by } \\
\text { China }\end{array}$ \\
\hline 2013 & 150 & $2(1.33)$ & 0.116 & 0.035 & 0.3 \\
\hline 2014 & 133 & $16(12.0)$ & 0.100 & 0.024 & \\
\hline
\end{tabular}

Table 4. Level of Mercury in raw milk in 2013, 2014

\begin{tabular}{|c|c|c|c|c|c|}
\hline Year & $\begin{array}{c}\text { Sample } \\
\text { size }\end{array}$ & $\begin{array}{c}\text { Undetected } \\
\text { no.(\%) }\end{array}$ & $\begin{array}{c}\text { Maxim } \\
\mathrm{um} \\
(\mathrm{mg} / \mathrm{kg})\end{array}$ & $\begin{array}{c}\text { Mean } \\
(\mathrm{mg} / \mathrm{kg})\end{array}$ & $\begin{array}{c}\text { Maximum } \\
(\mathrm{mg} / \mathrm{kg}) \\
\text { Set by } \\
\text { China }\end{array}$ \\
\hline 2013 & 150 & 0 & 0.008 & 0.004 & 0.01 \\
\hline 2014 & 133 & 0 & 0.009 & 0.003 & \\
\hline
\end{tabular}

\subsection{Results and Discussion}

\subsubsection{Analysis of : Lead}

$1.82 \%$ of the raw milk didn't contain lead in 2012. In $2013,97 \%$ of the raw milk was not contained lead. In $2014,65.5 \%$ of the raw milk was not contained lead. Among the three years, the maximum content was 0.048 $\mathrm{mg} \cdot \mathrm{kg}^{-1}$ in 2012, and the Minimum content was 0.0047 $\mathrm{mg} \cdot \mathrm{kg}^{-1}$ in 2014. Can be seen from above (Table 1), none of Lead content exceeded the Maximum Limit set by China. The mean content was reducing, and the conclusion may be drawn the concentrations of lead in raw milk are lower, with an reducing trend every year.

\subsubsection{Analysis of : Arsenic}

As shown in table 2, 91\% of the raw milk didn't contain Arsenic in 2014. The maximum concentration was 0.031 $\mathrm{mg} \cdot \mathrm{kg}^{-1}$, and the Minimum was $0.0018 \mathrm{mg} \cdot \mathrm{kg}^{-1}$. Table 2 displays that none of Arsenic contents exceeded the Maximum Limit set by China. To investigate the latter, we would keep monitoring the parameter regularly and guide ours work.

\subsubsection{Analysis of : Chromium}

It can be seen from Table $3,1.33 \%$ of the raw milk was not contained Chromium in 2013 and $16 \%$ of the raw milk was not contained Chromium in 2014. In the two years, the maximum content was $0.116 \mathrm{mg} \cdot \mathrm{kg}^{-1}$ in 2013 , and the Minimum content was $0.0012 \mathrm{mg} \cdot \mathrm{kg}^{-1}$ in 2014 . None of Chromium content exceeded the Maximum Limit set by China. Significantly, the content of Chromium in 2014 is lower than the content of Chromium in 2013.

\subsubsection{Analysis of : Mercury}

The figures in Table 4 indicated $9 \%$ of the raw milk was not contained Mercury in 2013 and all the raw milk was contained Mercury in 2014. In the two years, the maximum content was $0.009 \mathrm{mg} \cdot \mathrm{kg}^{-1}$ in 2014 , and the Minimum content was $0.001 \mathrm{mg} \cdot \mathrm{kg}^{-1}$ in 2013 and 2014 . None of Lead content exceeded the Maximum Limit set by China. We should strengthen the work of testing the residual mercury.

\section{Conclusion}

From what has been mentioned above, we may draw the conclusion that levels of Chromium in milk is higher, followed by levels of Arsenic, lead, and Mercury. None of heavy metals (Lead, Arsenic, Chromium and Mercury) content exceeded the Maximum Limit set by China ${ }^{[9]}$. The mean content was reducing, and the conclusion may be drawn the concentrations of lead in raw milk are lower, with an reducing trend year to year. Because of the high detection rates in raw milk, we should strengthen the work of testing the residual of the heavy metals (Lead, Arsenic, Chromium and Mercury), and control measures need to be strictly enforced in order to keep these heavy metals in a safe level and ensure that the milk is safe for people to drink ${ }^{[18-19]}$.

\section{Acknowledgement}

Thanks to all the colleagues who contributed to the success of this work. 


\section{References}

1. Amponsah D International Journal of Advancements in Research \& Technology . 3, (2014)

2. N. Gougoulias1, S. Leontopoulos, Ch. Makridis J. Food Agric. 26, (2014)

3. Alok P D, Susmita M. Journal of Environmental Research And Development. 2, (2008)

4. Jun T, Zhu H, XiaoDong Pan Environmental Geochemistry and Health . 36,(2014)

5. K. Girma, Z. Tilahun, D. Haimanot. World Journal of Dairy \& Food Sciences . 9, (2014)

6. Mehrdad T, M. Ahmadi F, H. Poursoltani, A. Salah Nejad, A.A. Motallebi, H. Mahdavi . Food Control. 19, (2008)

7. Ravindra K G, Mahesh C, Sanjay K. S. Wastewater Reuse and Management .11,(2013)

8. Neelam U, Ankit G, Anil K, Darshan L G, Richa S. 10,(2014)

9. Xueyin Q, Baiqin Zh, Nan Zh, Jiaqi W, Xiaomin X, Rongwei H,Yunpeng Zh, Songli L . Agriculture \& Environment .11,(2003)

10. Samuel M, Eric L, Frédéric G, Nadia C, Pierre B. Food Chemistry .129,(2011)

11. Laurence M B, Irma Q, Jean L G, Olaf M.Royal Swedish Academy of Sciences (1999)

12. Mohammad R, Hajar A D, Hassan J, Ali F, Arman Sh, Hossein J, Hossein T, Mohammad Y, Ali A M.World Journal of Dairy \& Food Sciences.5, (2014)

13. Hajar A D, Hassan J, Ali F, Arman Sh, Hossein J, Hossein T, Mohammad Y, Ali A M. Health. 6, (2014)

14. Y.D. Zhang, N.Zheng, R.W.Han, B.Q. Zheng, ZN.Yu, S.L.Li, S.S.Zheng. Food Control .36,(2014)

15. L.C.Huang, N. Zheng, B.Q. Zheng, F.Wen, J.B.Cheng, R.W. Han, X.M. Xu, S.L.Li, J.Q. Wang Simultaneous determination of aflatoxin M1, ochratoxin A, zearalenone and $\alpha$-zearalenol in milk by UHPLC-MS/MS. Food Chemistry. 146,(2014)

16. Liansheng $\mathrm{Zh}$, Baiqin $\mathrm{Zh}$, Nan $\mathrm{Zh}$, Songli L, Han $\mathrm{Hu}$, Yangdong Zha, Jiaqi Wang. Agriculture and Environment 12(2014)

17. Habte G, JiYeon Ch, EunYeong N, SangYeol O, Naeem K, Hoon Ch, KyungSu P, KyongSu K. Food Science and Biotechnology. 24(1),(2015)

18. Mahboob Sh, Al-Balwai, H. F. A., Al-Misned, F, Al-Ghanim, K. A., Ahmad, Z.. Toxicological and Environmental Chemistry .96,(2014)

19. Jiandong Zh, Xilin L . Chinese Journal of Preventive Medicine article.21,(1987) 